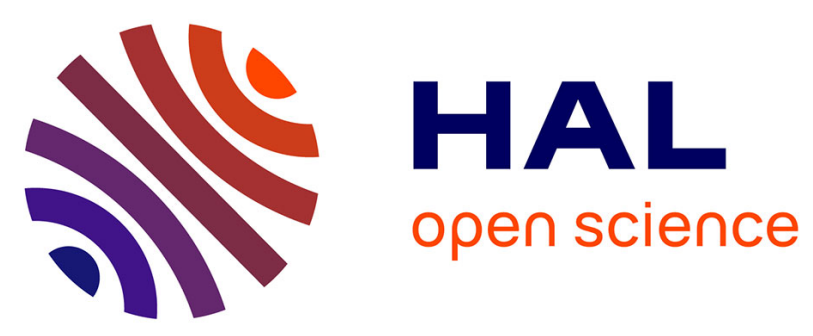

\title{
Study and characterization of wear and heat phenomena, for metallic and composites aircrafts' structural materials, during emergency landings.
}

Tovignon Devo, Didier Joly, Arnaud Beaurain, Éric Deletombe, Yannick

Desplanques

\section{To cite this version:}

Tovignon Devo, Didier Joly, Arnaud Beaurain, Éric Deletombe, Yannick Desplanques. Study and characterization of wear and heat phenomena, for metallic and composites aircrafts' structural materials, during emergency landings.. 17th LACCEI, Jul 2019, MONTEGO BAY, Jamaica. 10.18687/LACCEI2019.1.1.504 . hal-02393400

\section{HAL Id: hal-02393400 \\ https://hal.science/hal-02393400}

Submitted on 4 Dec 2019

HAL is a multi-disciplinary open access archive for the deposit and dissemination of scientific research documents, whether they are published or not. The documents may come from teaching and research institutions in France or abroad, or from public or private research centers.
L'archive ouverte pluridisciplinaire HAL, est destinée au dépôt et à la diffusion de documents scientifiques de niveau recherche, publiés ou non, émanant des établissements d'enseignement et de recherche français ou étrangers, des laboratoires publics ou privés. 


\title{
Study and characterization of wear and heat phenomena, for metallic and composites aircrafts' structural materials, during emergency landings.
}

\author{
Tovignon DEVO, PhD Student ${ }^{1,2}$, Didier JOLY, Research Engineer ${ }^{1}$, Arnaud BEAURAIN, Research Engineer ${ }^{2}$, Eric \\ DELETOMBE, Senior Research Scientist ${ }^{1}$, and Yannick DESPLANQUES, Professor ${ }^{2}$ \\ ${ }^{1}$ Onera - The French Aerospace Lab, DMAS/CRD, Lille, France, tovignon.devo@onera.fr, didier.joly@onera.fr, \\ eric.deletombe@onera.fr \\ ${ }^{2}$ Univ. Lille, CNRS, Centrale Lille, FRE 2016 - LaMcube - Laboratoire de mécanique, multiphysique, multiéchelle, F-59000 Lille, \\ France, arnaud.beaurain@univ-lille.fr,yannick.desplanques@centralelille.fr
}

\begin{abstract}
Aviation is one of the safest public transport means today. To reach such a performance, aircraft safety mainly relies on experience feedbacks and a set of constantly evolving rules which concern the flying products and operations. This also works for emergency landings or crash situations wherein the aircraft "belly" is directly in contact with the runway (Figure 1).

For this purpose, a four years research project (PHYSAFE) funded by the French DGAC started in August 2015. Part of the research aims at experimentally studying and characterizing various phenomena which may have a noticeable influence on aircraft passengers' safety in case of emergency landing or crash. Among these experimental studies, the development of test means and facilities to characterize the dynamic wear behavior of aircraft primary structure materials once in contact with the ground was selected as being of common interest for aircraft and rotorcraft airframes.
\end{abstract}

The part of the PhD work to be presented is notably focusing on the study and characterization of wear and heat phenomena, for metallic and composites aircraft structural materials (reference materials: Au2024, T700/M21) during emergency landing situations. It aims at estimating (through "pin on disc" tests [1]) the main phenomena and principles to be taken into account for an experimental protocol (test bench, specimens, instrumentation, etc.) dedicated to the study of wear and heat of materials in representative conditions, followed by a first comparison of metallic and composite reference materials performances.

The methodology set up to partially answer the studied problematic, starts with pin-on-disc tests using a concrete pad and discs made of aluminum or composite material. The preliminary experimental design permits to observe the results of interactions between concrete and the materials like in an aircraft fuselage.

A first identification of the tribological systems representing the studied contact, aims at defining the first bodies and the third body produced within the studied contacts. Once the tribological mechanisms identified (by post mortem and in-situ analysis), an estimated dissipated energy may be linked to those mechanisms through the writing of material and energy balances [2,3].

A future step of the work would concern the study of possible similitude rules (through non-dimensional numbers establishment relying on the Vaschy-Buckingham's theorem [4]), for a selection of identified wear and abrasion mechanisms, to check the possible extrapolation of experiments at a laboratory scale at full-scale level. landing.

Keyword: wear, friction, tribology, experiments, emergency

Digital Object Identifier (DOI):

http://dx.doi.org/10.18687/LACCEI2019.1.1.504

ISBN: 978-0-9993443-6-1 ISSN: 2414-6390

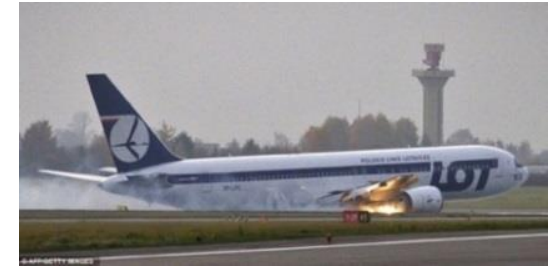

Fig. 1 LOT Boeing 767 from Newark to Warsaw Emergency Landing with no landing gear (Getty Images).

\section{TRIBOLOGICAL SYSTEM \& PRELIMINARY TESTS}

A. Tribological system

In the studied problem, a tribological system can be defined including two first bodies (fuselage and runway), defining the contacting materials and surfaces, and a third body produced by the interactions of the two first bodies. Furthermore, the tribological system includes also the working system, here the whole aircraft and the landing area, defining the load and the sliding conditions, one of the main parameters been the stiffness.

\section{B. Preliminary tests}

The objective of the study is to design a reduced scale experiment to study the crash situation in a laboratory. However, it remains important to identify and understand tribological mechanisms that occur within the contact between an aircraft body and a concrete runway, which are up to now completely unknown. Therefore, preliminary pin-on-disc tests were realized using a concrete pad (as the runway material) and an A12024 aluminum alloy disc (or a T700/M21 carbon fiber reinforced polymer composite.) The parameters chosen for the tests are presented in Table 1.

\section{MATERIAL \& ENERGY BALANCES}

Having defined the tribological triplet, one may write a material balance (1) to characterize the wear of the 2 first bodies (disc, pad). For each first body, the wear would here represent the loss and possibly gain of materials during the contact then, considering the third body, one can obtain:

$$
\begin{aligned}
& M^{i f s t \text { body }}(t)=M_{\text {initial }}^{\text {ifst body }}+\Delta M_{\text {lost or gain }}^{\text {ifst body }}(t) \\
& \sum \Delta M_{\text {lost or gain }}^{\text {ifst body }}(t)=\sum\left(Q_{s}+Q_{r}-Q_{e}-Q_{w}\right) \Delta t
\end{aligned}
$$

$17^{\text {th }}$ LACCEI International Multi-Conference for Engineering, Education, and Technology: "Industry, Innovation, And Infrastructure for Sustainable Cities and Communities”, 24-26 July 2019, Jamaica. 
where $Q_{j}$ represent incoming and outcoming flows of the third body into the contact.

Considering the thermodynamics first principle, assuming that the contribution of the potential energy is negligible compared to the other energies' contribution, the following energy balance may be written:

$$
\delta Q=d E c-d U-\delta W F \text { ext }
$$

Where $d U$ is the "internal energy" which is dissipated by tribological mechanisms (abrasion, oxidation, etc.) The works to be presented are dedicated to the study of these mechanisms i.e. identification, modelling, and quantification according to the tests conditions. In situ (infrared) and post-mortem (SEM, optical microscopy) analysis were used to support this study (Figure 2).
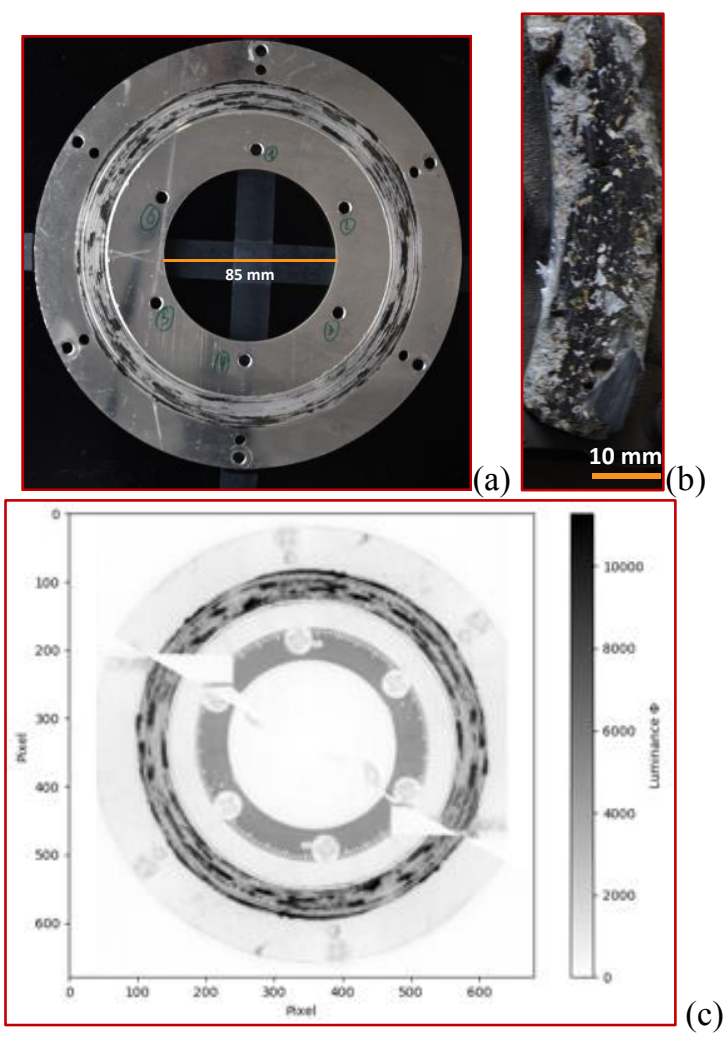

Fig. 2 Post-mortem aluminum disc (a) Post mortem concrete pad (b) IR image of the disc within the test (here at $\mathrm{t}=17$ seconds) (c)

\section{ANALYSIS OF RESULTS}

As described previously, a third body is produced within the contact and as different tests were carried with different parameters, it is interesting to identify its chemical and mechanical nature. That is to say to characterize its flow and determine if its production may reduce the wear or the loadbearing area.

Therefore, it was observed by SEM (Figure 3) revealing different phases present on the disc. The elements $\mathrm{Si}$ and $\mathrm{Ca}$ present in the concrete were detected upon the (Al) disc, as the main part of the third body (Figure 4).

\begin{tabular}{|c|c|c|c|c|c|}
\hline $\begin{array}{c}\text { Material } \\
\text { used }\end{array}$ & $\begin{array}{c}\text { Thickness } \\
\text { of the disc } \\
(\mathrm{mm})\end{array}$ & $\begin{array}{c}\text { Thickness } \\
\text { of the pad } \\
(\mathrm{mm})\end{array}$ & $\begin{array}{c}\text { Rotation } \\
\text { speed } \\
(\mathrm{rpm})\end{array}$ & $\begin{array}{c}\text { Charge } \\
(\mathrm{kN})\end{array}$ & $\begin{array}{c}\text { Duration } \\
(\mathrm{s})\end{array}$ \\
\hline \multirow{4}{*}{$\begin{array}{c}\text { A12024/ } \\
\text { T3 }\end{array}$} & 1.4 & 8 & 2000 & 1 & 20 \\
\cline { 2 - 6 } & 1.6 & 11 & 2000 & 0.5 & 20 \\
\cline { 2 - 6 } & 3 & 11 & 1000 & 1 & 20 \\
\cline { 2 - 6 } & 3.5 & 10 & 2000 & 0.5 & 50 \\
\hline \multirow{2}{*}{ T700/ } & 4 & 11 & 2000 & 1 & 20 \\
\cline { 2 - 6 } M21 & 4 & 10 & 2000 & 1 & 20 \\
\cline { 2 - 6 } & 4 & 10 & 1000 & 0.1 & 20 \\
\hline
\end{tabular}

Table 1 Parameters of the preliminary tests realized

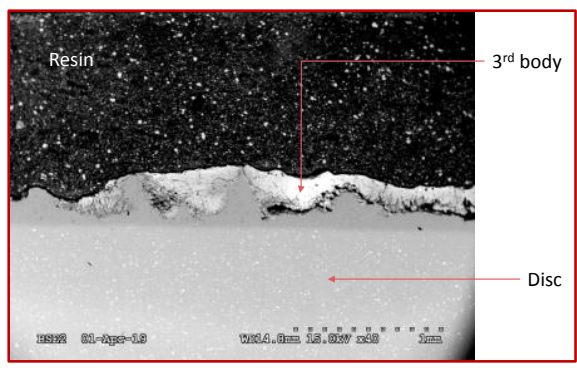

Fig. 3 BSE post-mortem radial section analysis of a part of the surface of the disc/pad contact

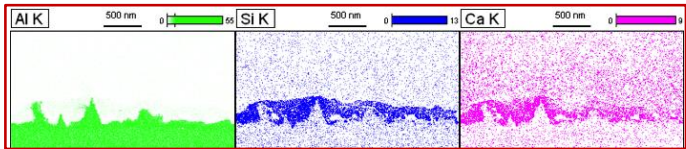

Fig. 4 EDS post-mortem radial section analysis of a part of the surface of the disc/pad contact

\section{ACKNOWLEDGMENT}

The authors thank A. Mège-Revil (Lecturer) and D. Najjar (Professor) for assistance with SEM analysis to be presented at the conference. The authors gratefully acknowledge the french DGAC that supports the PHYSAFE project, the European Union with European Regional Development Fund, the French State and the Hauts-de-France Region Council that support ELSAT 2020 project.

\section{REFERENCES}

[1] Deletombe, E., Berthe, J., Fourest, T., Portemont, G., Joly, D., Castres, M., \& Bigault, L. (2018). PHYSAFE - Study and characterization of the dynamic response of materials for the improvement of crash behavior of aircraft structures - Scientific Report 2018 PROPERTY OF ONERA, (May).

[2] Romain Mandard, Yannick Desplanques, Grégory Hauss, Jacky Fabis, Jean-François Witz, Jean Meriaux, Mechanisms of incursion accommodation during interaction between a vibrating blade and an abradable coating,Wear,Volumes 330-331,2015,Pages 406-41.

[3] Quentin Agrapart, Jean-François Brunel, Yannick Desplanques, Philippe Dufrenoy, Romain Mandard, et al.. An energy balance of blade-casing interaction. 16th International Symposium on Transport Phenomena and Dynamics of Rotating Machinery (ISROMAC 2016), Apr 2016, Honolulu, United States.

[4] E. Buckingham. On physically similar systems: illustrations of the use of dimensional equations, 1914.

[5] Y. Desplanques, O. Roussette, G. Degallaix, R. Copin, and Y. Berthier. Analysis of tribological behaviour of pad-disc contact in railway braking. Part 1. Laboratory test development, compromises between actual and simulated tribological triplets. Wear, 262(5-6):582. 